\title{
Biologia, natureza e República no Brasil nos escritos de Mello Leitão (1922-1945)
}

\author{
Biology, nature and the Republic in Brazil \\ in the writings of Mello Leitão (1922-1945)
}

Regina Horta Duarte *

Resumo

Nas primeiras décadas do século XX, constituiu-se um campo específico do conhecimento biológico no Brasil, com forte instrumentalização política desse saber. Iniciativas de divulgação científica da biologia foram decisivas nesse contexto, com destaque para as práticas de cientistas do Museu Nacional do Rio de Janeiro, nas quais se delinearam concepções favoráveis à construção de um Estado forte e centralizado. Nesse contexto, esta análise privilegia as práticas científicas do aracnólogo Cândido Mello Leitão (18861948) cientista prestigiado e autor de renome em sua época. Sua vida científica assumiu aspectos de militância, com grande dedicação à divulgação científica e, sobretudo, à sistematização de determinada visão da vida animal e da natureza como ponto de partida para a defesa de concepções políticas autoritárias.

Palavras-chave: história da biologia; pensamento autoritário; natureza e sociedade; Mello Leitão.

\begin{abstract}
The first decades of the 20th century saw biology become a very specific field of knowledge, and also become characterized by the political use of this knowledge. Initiatives taken in the scientific divulgation of biology were decisive in that context. The activities of scientists at the Museu Nacional of Rio de Janeiro stood out as they favored the construction of a strong and centralized state. The present analysis focuses on the scientific practices of the arachnologist Cândido Mello Leitão (1886-1948), a renowned scientist and author in his time. He was intensely engaged in the scientific life, with great dedication to scientific divulgation, mainly to the systematization of a certain view of animal life and nature as the starting point for a defense of authoritarian political points of view.
\end{abstract}

Keywords: history of biology; authoritarian thought; nature and society; Mello Leitão.

\footnotetext{
* Pesquisadora CNPq; Professora do Departamento de História da UFMG. Av. Antonio Carlos 6627, Prédio da Fafich, Sala 4130.31270-901 Belo Horizonte - MG - Brasil. reginahd@uai.com.br
} 
A história da ciência no Brasil possui importante capítulo referente à divulgação dos conhecimentos científicos entre o público leigo, assim como à construção de determinadas representações acerca da natureza, em diferentes épocas e através de meios diversos. O presente trabalho enfoca as iniciativas de divulgação científica da biologia entre 1922 e 1945, período crucial da história da República neste país e marcado pelo divisor de águas em que se transformou a chamada "Revolução de 1930". No processo de difusão de certas concepções acerca da natureza por meio das práticas dos biólogos, ocorreu uma politização explícita desses saberes, muitas vezes utilizados como base teórica para a defesa de posturas específicas acerca da constituição nacional. Naqueles anos, confrontaram-se vários projetos de uma nação moderna, num contexto internacional decisivo e conturbado, com intensos debates internos sobre a formação do povo e o papel do Estado na condução da sociedade. Nesse contexto tão amplo e multifacetado, privilegiaremos as práticas do cientista Cândido de Mello Leitão, que assumiu papel ativo entre seus contemporâneos e encontrou especial destaque na rede de relações construída em torno de várias associações científicas e educacionais do Brasil de então.

Os primeiros textos de divulgação científica de Mello Leitão datam de 1922. Em coluna semanal em um jornal do Rio de Janeiro, publicou artigos sobre eugenia, hereditariedade, evolução e história natural, mas também sobre a revolução russa e o avanço do comunismo no mundo, sobre a guerra e o imperialismo, assim como sobre fé e religião. O ano de 1922 apresentou-se como uma confluência de várias possibilidades históricas em jogo na sociedade brasileira, com a Semana de Arte Moderna, a fundação do Partido Comunista do Brasil, as revoltas militares dos tenentes, as comemorações do centenário da Independência do Brasil, a Exposição Universal no Rio de Janeiro, a primeira emissão radiofônica no país e a eleição do presidente Artur Bernardes, que assumiu o poder sob estado de sítio e governou durante quatro anos sob o signo da censura e da repressão violenta aos opositores. As marcas da Primeira Guerra Mundial instauravam um grande questionamento dos caminhos vividos pela Europa, levantando a pertinência do "sonho americano"; a influência e a proximidade crescentes dos Estados Unidos da América tornavamse decisivas para toda uma geração de intelectuais.

Estendendo-se até 1945 - ano em que Mello Leitão realiza uma importante viagem a Montevidéu como "embaixador cultural" do Brasil -, nossa análise privilegia ainda a publicação de $A$ vida maravilhosa dos animais, livro desse autor sobre curiosidades da vida animal, dedicado a um público leigo e com textos muito diversificados. Possuía linguagem simples, direta e didática, 
mas também carregada de grandes pretensões poéticas e literárias, numa clara estratégia de sedução dos leitores. O sucesso da obra foi grande, tendo saído a primeira edição em 1935 e uma segunda em 1944.

Ao longo desses anos, Cândido de Mello Leitão alcançou grande prestígio como zoólogo, exerceu cargos e missões importantes junto aos órgãos governamentais e obteve sucesso editorial com a publicação de inúmeros livros. Sua vida científica assumiu ares de militância, com ampla dedicação à divulgação dos conhecimentos e, sobretudo, com utilização de sua visão acerca da vida animal e da natureza como ponto de partida para a defesa de várias concepções relacionadas à vida humana e aos rumos da sociedade brasileira, que vivia anos decisivos da história de sua República. A atuação de Mello Leitão realizou-se num contexto mais amplo de articulação política dos saberes biológicos, nas primeiras décadas do século XX, em consonância com a ascensão de projetos políticos autoritários de constituição da nação.

\section{“Conselhos aOs JOVENS zoólogos”: BIOLOGIA E POLÍticA}

Em 1931, o entomólogo do Museu Nacional Cândido de Mello Leitão foi nomeado, pelo Ministério da Educação e Saúde Pública, "embaixador intelectual" do Brasil para viagem ao Uruguai e à Argentina, numa política de ampliação de relações culturais com os países vizinhos. Os jornais de Montevidéu anunciaram amplamente a chegada do "destacado zoólogo brasileiro", que visitou instituições de ensino e pesquisa, proferiu palestras sobre aranhas e escorpiões - sua especialidade -, discutiu questões relacionadas à educação de jovens e realizou intercâmbio de material de pesquisa com entomólogos do Museu de História Natural de Montevidéu. Na sequência de sua viagem, visitou Buenos Aires, com atividades similares. Alguns anos depois, em 1945, dois meses antes do fim do Estado Novo, Mello Leitão foi nomeado novamente "embaixador cultural" brasileiro, em uma viagem a Montevidéu. Nessa cidade, realizou conferências no Instituto Histórico, no Museu de História Natural e no Instituto de Investigações Geográficas. Ofereceu-se como debatedor - numa espécie de workshop -, numa seção denominada "Conselhos aos jovens zoólogos”. Dali, Mello Leitão seguiu para a Argentina, onde proferiu palestras na Universidade de La Plata, na Sociedade Argentina de Entomologia e no Museu Argentino de Ciências Naturais. Nessa ocasião, foi homenageado com a inauguração de seu retrato nas salas de entomologia dos Museus de La Plata e Buenos Aires. Ao despedir-se de seus colegas, comemorava a criação de uma verdadeira "colmeia de devotados cultores da aracnologia", ressaltando a de- 
dicação de toda a sua própria vida ao estudo de espécimes latino-americanas - além daquelas comuns no território brasileiro. ${ }^{1}$

Certamente a indicação de Mello Leitão para as duas viagens deve ser explicada pelas suas atividades como entomólogo e mesmo pela importância de sua produção na área. Médico pediatra formado na Faculdade de Medicina do Rio de Janeiro, filho de uma numerosa, tradicional e católica família de cidade de Campina Grande, na Paraíba, dedicou-se ao estudo da zoologia desde a década de 1910, quando se tornou professor da Escola Superior de Agricultura e Medicina Veterinária em Piraí (RJ). Especializou-se em aracnídeos, descreveu inúmeras espécies, publicou 198 artigos científicos em revistas especializadas sobre taxonomia de Arachnida, assim como catalogou 59 mil invertebrados ao longo de sua vida. Organizou expressivas coleções, uma primeira com 2.341 espécimes, vendida ao Museu Nacional, uma segunda doada à mesma instituição em 1948. Também realizou doações ao Museu Argentino de Ciências Naturais Bernardino Rivadavia (Buenos Aires), ao Museu de La Plata, mas também ao Museu de História Natural de Paris e ao Museu Britânico de História Natural. Durante décadas, realizou intensa troca de insetos, com pedidos de exemplares de várias partes do Brasil e do mundo, assim como envio de outros. Empreendeu intenso intercâmbio científico, pelo correio, de vidros cheios de exemplares preservados em formol, trânsito esse facilmente comprovado em detalhes pela leitura de sua correspondência pessoal, numa verdadeira rede de envio de aranhas e escorpiões entre vários países. Atuou como professor de biologia em colégios e faculdades de agronomia, foi pesquisador do Museu Nacional, escreveu vários livros didáticos de ampla aceitação em escolas brasileiras e dedicou-se com impressionante fervor à divulgação científica. Participou ainda da organização da exposição de invertebrados no Museu Nacional, bem como da publicação de textos em jornais, revistas elivros, e colaborou em programas radiofônicos educativos. Pertenceu ao Conselho Nacional de Geografia e à Academia Brasileira de Ciências (da qual foi presidente entre 1943 e 1945). Ao longo de sua vida, manteve intensa correspondência científica com pesquisadores de diversas instituições internacionais. Sua ampla produção científica incluiu artigos em várias revistas brasileiras e, também, em revistas chilenas, argentinas e uruguaias. Entre os textos publicados em revistas especializadas podemos indicar vários sobre aracnídeos nativos dos territórios de vários países sul-americanos, como Argentina, Uruguai, Chile, Peru e Equador. ${ }^{2}$

Assim, a sua indicação para as missões culturais, tanto em 1931 quanto em 1945, não foi casual. Até hoje, cientistas dedicados ao estudo de aracnídeos 
apontam a importância de sua produção. Não obstante sua competência científica, a indicação de Mello Leitão guiou-se também, e talvez mais decisivamente, pelo significado que a sua figura adquiriu ao longo daqueles anos, dentro de um contexto mais amplo de instrumentalização política dos conhecimentos biológicos e da sua consonância com um projeto político nacional autoritário.

A escolha desse cientista como "embaixador cultural" nos dois diferentes momentos de articulação política trazia significativas implicações. Externamente, o governo contava com um representante suficientemente competente para ser bem recebido nas melhores instituições científicas de outros países da América Latina, como no Uruguai e na Argentina. Internamente, cumpriase o coroamento de determinadas perspectivas de sociedade francamente autoritárias, escudadas pela excelência científica do respeitado biólogo, capaz de seduzir seus leitores com uma escrita leve e agradável: além da circulação entre os meios científicos, Mello Leitão foi ativo na chamada "vulgarização do conhecimento científico" (na expressão da época) entre o público leigo, como também na construção de determinadas representações acerca da natureza, em diferentes épocas de sua vida e por meios diversos.

As ciências biológicas receberam grande impulso no Brasil desde o início do século XX. Constituiu-se como um dos fundamentos das práticas higienistas, possibilitando a experiência de uma Belle Époque em cidades como Rio de Janeiro (antes dominada pela febre amarela e pela varíola) e São Paulo (que, pela proximidade ao porto de Santos, viu-se aterrorizada, na passagem do século, com a iminência do contágio pela peste). Fundaram-se centros laboratoriais de pesquisa, como o Instituto Soroterápico Federal (1900), atual Fundação Oswaldo Cruz, e o Instituto Serumtherápico (1901), atual Instituto Butantã, para produção de soros diversos, mas também para os estudos de doenças tropicais, fisiologia, bioquímica e entomologia aplicada. $\mathrm{O}$ avanço das lavouras de café, riqueza principal das elites agroexportadoras naqueles anos, e a necessidade do enfrentamento de pragas, como nos casos clássicos da saúva ou da broca do café (consequência da ação de um besouro), levaram à valorização dos saberes botânicos e entomológicos. ${ }^{3}$

Somado a esses eventos, ocorreu um significativo avanço da ocupação do território, relacionado à construção de ferrovias, instalação de linhas telegráficas e estabelecimento mais rigoroso das fronteiras. Desencadearam-se, então, intensos debates sobre as riquezas naturais - fauna, flora, solo, subsolo - assim como sobre o absurdo da exaustão da terra e da gente por séculos de exploração imprevidente e imediata, num país de elites violentas e egoístas. Paralela- 
mente, houve encontros com várias populações indígenas, até então afastadas do contato com a civilização, e a invenção de um sertão profundo, no qual os intelectuais passaram a enxergar a origem da mais pura nacionalidade através da figura do sertanejo, norteados pelas imagens eternizadas no clássico livro Os sertões (1902) de Euclides da Cunha. Um intenso debate sobre as características raciais do povo brasileiro a partir dos paradigmas da eugenia e da genética - envolvendo releituras de Galton, Mendel e outros teóricos da biologia - passou a mobilizar grande número de intelectuais. ${ }^{4}$

Nesse contexto, o Museu Nacional, situado no Rio de Janeiro, tornou-se importante centro intelectual de debate e lócus formador de projetos de renovação nacional. Seus membros integraram um crescente movimento de especialização dos saberes, que os diferenciaria dos 'naturalistas' do século XIX. A biologia se constituía como uma prática científica que extrapolava a descrição e classificação de espécies, voltando-se para o estudo do ser vivo em suas relações ecológicas e biogeográficas, como também em seus aspectos fisiológicos, genéticos e evolutivos. ${ }^{5}$ Essa ciência viabilizaria um caminho original em direção a um futuro próspero, baseado na exploração racional e equilibrada dos recursos naturais visando os contemporâneos e as gerações futuras.

O caráter marcadamente pedagógico das práticas dos cientistas do Museu Nacional relacionou-se ao predomínio de concepções políticas em prol da construção de um Estado centralizado, forte, supostamente acima dos interesses e apetites individuais, garantindo a superação da miséria material e espiritual de populações até então abandonadas à própria sorte, à doença, à fome e à ignorância. Nesse sentido, intelectuais ligados ao Museu organizaram congressos de proteção à natureza, engrossaram movimentos de renovação da escola infantil e juvenil, envolveram-se na publicação das primeiras coleções de livros relacionados ao conhecimento do Brasil e foram os precursores das emissões radiofônicas no país, além de editores de revistas voltadas para um público leigo. A divulgação científica assumiu papel estratégico, em verdadeira tentativa de engajar variados tipos de leitores para uma ampla empreitada de transformação da sociedade. ${ }^{6}$

Curiosamente, os cientistas brasileiros não estavam isolados nessas práticas nas quais se uniam desejo de conhecimento e intenções de transformação política e social. Em vários outros países da América Latina, da América do Norte e da Europa, os biólogos passaram a ser importantes interlocutores nos debates sobre a nação, o território e a população, assim como artífices de novos projetos para a sociedade, num instigante contexto apontado por alguns estudiosos como a "era da biologia". ${ }^{7}$ As representações sobre a natureza ganharam 
um paralelo verdadeiramente estratégico com as representações sobre a sociedade, e, quando discutiam sobre animais e plantas, vários cientistas entremearam suas conclusões com observações diversas acerca de suas próprias sociedades e com prescrições sobre as transformações que julgavam necessárias.

\section{“DesígNios INSONDÁveIS": BIOLOGIA E CATOLICISMO}

A estreia de Mello Leitão no jornalismo de divulgação dos conhecimentos biológicos ocorreu no turbulento ano de 1922, e alcançou grande significado na autoavaliação de sua carreira. O zoólogo recortou um a um os artigos, datouos cuidadosamente e os reuniu em caderno de recortes do seu acervo pessoal, hoje preservado pelo Arquivo Histórico do Museu Nacional.

$\mathrm{O}$ autor não apenas dedicou-se à abordagem de temas biológicos ao alcance dos leigos, mas argumentou sobre a importância de fazê-lo num momento em que o ensino dos seres vivos realizava-se de forma entediante, árida e pouco acessível. Segundo sua avaliação, os colégios secundários possuíam cadeiras de História Natural deficientes: a botânica e a zoologia não recebiam o destaque devido, os programas pecavam pela falta de uniformidade, inexistiam aulas práticas e os cursos eram demasiado breves para garantirem um aprendizado real. Na Faculdade de Medicina do Rio de Janeiro, um público seleto recebia densa formação excessivamente teórica em cadeiras de História Natural, com leituras de Lamarck, Darwin e Haeckel, sem chegar a constituir qualquer conhecimento da flora e da fauna brasileiras. Nos vários níveis do ensino, portanto, o estudo da vida era menosprezado ou mal conduzido: não oferecia um conhecimento ligado à vida prática, não capacitava os estudantes ao entendimento de sua ligação ao mundo mais amplo dos seres vivos, sua dependência e sujeição às mesmas leis naturais, e não abria, portanto, a possibilidade de um saber que lhes permitisse regular essas leis em proveito da construção de uma nação brasileira. Para o autor, a história natural deveria ter "cunho essencialmente nacional, referida, sempre que possível, à flora, à fauna, ao solo brasileiros". ${ }^{8}$

Delineia-se aqui um argumento fundamental de toda a obra de Mello Leitão, acerca da importância política e social da biologia. Nesse ponto, ele se encontrava em consonância com muitos biólogos de seu tempo. Uma geração de cientistas empenhava-se, naqueles mesmos anos, para unir compreensão da natureza viva e nacionalismo, buscando sair dos limites da academia para dirigir-se à sociedade, num esforço para sua renovação. $\mathrm{O}$ século $\mathrm{XX}$ seria a "era da biologia", na qual a ênfase a uma abordagem experimental combinava- 
se com a defesa desse conhecimento como a chave para o entendimento do comportamento dos seres vivos, incluindo aí os seres humanos (Pauly, 2000, p.166-193).

Nessa perspectiva, os biólogos se autoatribuíram o papel de sábios capazes de prescrever medidas restauradoras da saúde de organismos sociais doentes. Afinados à economia da natureza perscrutada no estudo da morfologia experimental de plantas e animais, esses cientistas seriam também como profetas, verdadeiros evangelistas, aptos a revelar os ensinamentos morais contidos numa natureza predominantemente normativa, traduzindo de seus hieróglifos as leis ali inscritas por uma inteligência superior (Mitman, 1992, p.48-71).

Em artigo sobre a hereditariedade dos caracteres adquiridos, no qual contradizia os defensores dessa teoria, Mello Leitão aponta como tal polêmica constituía muito mais que mera especulação acadêmica. Antes, o debate sobre a evolução dos organismos relacionava-se à discussão decisiva acerca da eugenia, das possibilidades e limites da educação, interessando não apenas a biólogos, mas também aos médicos, educadores, moralistas e pregadores de reformas sociais. $^{9}$

A eugenia impulsionava o papel da biologia na constituição das nações, evidenciando como o conhecimento das leis da hereditariedade - mesmo que ainda muitos mecanismos permanecessem inexplicáveis - poderia viabilizar o desejo de melhoramento da raça humana ou mesmo levar à aceitação da inviabilidade de algumas delas. Argumentando que tais leis eram determinantes sobre os aspectos físicos e morais dos seres vivos - incluindo-se aí os seres humanos -, Mello Leitão julgava os limites da higiene, impotente sob as leis de ferro da hereditariedade. Diante da força de genes "defeituosos, dependentes e delinquentes" nada podia ser feito, a não ser evitar sua reprodução, restringindo o aumento dos indesejáveis. Citando leis norte-americanas de controle dos imigrantes, o autor lamentava a inexistência de fiscalização no Brasil, que poderia ser feita com o apoio do saber biológico: "ciosos do pedigree dos animais domésticos que importamos, ainda ninguém exigiu o pedigree humano". Da escolha de "boas sementes" dependeria o progresso das nações, e os cuidados possibilitados pelo conhecimento da genética seriam "as forças mais essenciais na futura evolução da sociedade humana". ${ }^{10}$

Para Mello Leitão, as perguntas primordiais do homem sobre a origem de toda a vida ao seu redor, desde as mais remotas eras, relacionavam-se ao que depois se desenvolvera como a biologia. O conhecimento da natureza constituíra-se como um fator de elevação espiritual do homem em direção à Verdade, ao Belo e ao Bem, ligando-o ao Criador Onisciente, desnudando a percep- 
ção de uma força vital onipresente, avassaladora e, sobretudo, enigmática. Deslumbrado diante de tais possibilidades, o sábio não deveria desprezar o mistério presente em todas as coisas: "mistério quanto à sua essência, mistério quanto às suas origens, mistério em suas infinitas mutações”. Frente ao fluxo universal e à complexidade da teia da vida, o biólogo deveria quedar-se, respeitoso, ante os arcana Dei. Ciência e religião apresentavam-se, em seu argumento platônico, como estradas paralelas em direção ao mesmo fim, a Verdade suprema inscrita por Deus no mundo sensível. Como exemplo, o zoólogo citava a proibição do casamento entre parentes pela Igreja Católica séculos antes de Mendel, Batenson e Davenport mostrarem como tais uniões aproximariam, perigosamente, genes recessivos. ${ }^{11}$

A referência ao mistério em torno da vida foi a pedra fundamental da oposição de nosso autor à seleção natural. $\mathrm{O}$ antidarwinismo predominou nos meios científicos no período entre guerras, quando essa teoria foi identificada à competitividade, ao imperialismo e aos enfrentamentos armados predominantes no panorama mundial. ${ }^{12}$ No Brasil, além dos horizontes internacionais turbulentos, somavam-se as dificuldades de uma República excludente e dominada por fortes oligarquias agroexportadoras, com o fortalecimento de movimentos operários em cidades como Rio de Janeiro e São Paulo, movimentos milenaristas nos sertões e ascensão do banditismo rural dos cangaceiros. $\mathrm{O}$ antidarwinismo dos meios científicos brasileiros das primeiras décadas do século XX ocorreu, portanto, num contexto de violência social e das lutas entre vários atores em torno das condições de trabalho e sobrevivência. ${ }^{13}$

Mello Leitão defendeu arduamente a possibilidade de uma visão biológica evolucionista, absolutamente alheia à seleção natural e harmoniosamente conciliada com uma perspectiva religiosa da vida. Para tanto, citava estrategicamente grandes nomes da ciência internacional, como William Bateson, difusor de Mendel no mundo de língua inglesa, professor da University of Cambridge que, em palestra científica de 1921, teria defendido - segundo nosso autor - uma fé inabalável na evolução, ao mesmo tempo em que desacreditara completamente os mecanismos da seleção natural. O biólogo brasileiro evocava a autoridade do inglês para defender-se contra aqueles que sempre atacavam os católicos como obscurantistas e retrógrados, como se evolucionismo e fé não pudessem conviver. Aceitando a evolução, mas repelindo a seleção natural, afirmava o mistério da origem das espécies, das transformações, da extinção, problemas para os quais não havia respostas claras, "como tantos outros dogmas de fé científica”, e que seriam talvez um dia desvendados. ${ }^{14}$

Naqueles anos de lutas sociais e definição de novos rumos para o Brasil, 
Mello Leitão apresentou-se, em suas colunas de jornalismo de divulgação científica, como um porta-voz da conciliação entre razão e fé, assim como da rejeição a uma perspectiva materialista da vida. Em artigo sobre o vitalismo, afirmava a inexistência de qualquer argumento capaz de contrariar tal perspectiva sobre a natureza, evocando os limites da química e da física para explicarem o fenômeno da vida. Dedicou ainda inúmeras páginas a negar uma origem comum entre o homem e o macaco, utilizando-se sempre de referências científicas internacionais, buscando combater tal perspectiva no domínio da razão, mas sempre explicitando a adesão explícita à perspectiva religiosa, opondo-se à identificação entre catolicismo e ignorância por "gente que por aí passeia o vulto de paquiderme".

Na concepção de natureza que Mello Leitão difundia aos seus contemporâneos, havia lugar para o movimento e para a transformação, mas esses seriam realizados num ambiente pacífico, harmonioso, no qual predominariam "os socorros" e não os combates, e a competição e a luta seriam superados pelo altruísmo e pela solidariedade. Afirmando-se admirado perante os "desígnios insondáveis da Providência”, o aracnólogo argumentava a existência de uma "teia da vida". Nela, o homem era um dos elos de uma intrincada "cadeia cósmica regida por uma inteligência superior”, acessível através da busca da Essência, ao contrário das "visões monstruosas" da luta pela existência e do predomínio do mais apto, "que os povos pretenderam aplicar em suas relações com outros povos". ${ }^{15}$

Nem sempre Mello Leitão mantinha sua clara estratégia de defender suas concepções apenas no âmbito da argumentação científica. Em junho de 1922 o Partido Comunista Brasileiro foi declarado ilegal, e iniciou-se um período de acirramento da repressão aos movimentos sociais de vários matizes, com o decreto de estado de sítio. No mesmo mês, um artigo sobre Dostoiévski abordava os perigos da revolução comunista, evento "devastador e catastrófico", quando emergiam "pretensões egoístas e interesseiras, verdadeiras maquinações niilistas e terroristas". Dostoiévski teria, segundo nosso autor, pressentido todas as misérias do bolchevismo, e os irmãos Karamazov seriam seus precursores, com a negação de Deus, da religião da sociedade e do respeito humano. $\mathrm{O}$ Partido Comunista pretensamente se apoiava na razão, tudo fazendo para desacreditar a religião como ignorância, numa falsa valorização do materialismo, "mergulhando o povo russo na servidão e no sofrimento".

Na conciliação entre ciência e religiosidade, Mello Leitão afinava-se a um movimento mais amplo então em curso na sociedade brasileira. Grupos católicos organizavam-se em direção a uma presença maior nas decisões do Estado 
e na educação. Em 1921, grupos católicos e conservadores do Rio de Janeiro se organizaram em torno do jornal $A$ ordem, um dos grandes defensores da candidatura de Artur Bernardes em oposição à de Nilo Peçanha, identificado como revolucionário e maçom. Em 1922, a fundação do Centro Dom Vital, no Rio de Janeiro, para estudo e promoção da doutrina católica, representou um marco da ação cristã no avanço de um projeto político conservador. Naqueles anos ganhava força um sindicalismo promovido pela Igreja Católica, baseado na concepção de harmonia entre capital e trabalho e no respeito à ordem vigente, com ação direcionada à implantação de uma legislação trabalhista.

A sintonia de um cientista e professor de renome com essa reação e o alcance de sua coluna jornalística certamente não eram pouco importantes naquele momento. A biologia de Mello Leitão apresentou-se também como um projeto político eminentemente reacionário. Opunha-se a uma visão materialista, valorizando a perspectiva religiosa da natureza e conciliando-a com a razão. Utilizava-se dos estudos de hereditariedade e da genética para defender o controle da imigração. Alertava para a entrada de "homens imprestáveis", nos mesmos anos em que o Estado brasileiro - após décadas de imigração em massa para atender às necessidades de uma mão de obra tanto mais barata quanto mais numerosa - identificava o trabalhador estrangeiro com a importação de doutrinas revolucionárias anarquistas e comunistas. Sobretudo, apostava numa perspectiva da sociedade calcada na harmonia, no entendimento, na cooperação, exorcizando o conflito e as lutas sociais como práticas degeneradas. Mediante a divulgação da perspectiva de um mundo natural organizado como uma teia da vida, holística, equilibrada e perfeita, reflexo do mundo das essências e fruto da criação divina, Mello Leitão desejou muito mais que instruir seus contemporâneos acerca das novas descobertas biológicas.

\section{ERUDIÇÃO VERSUS ERROS VULGARES: BIOLOGIA E EDUCAÇÃO}

Em fins de 1933, o professor Mello Leitão, membro da comissão nomeada pelo governo para a elaboração de um anteprojeto de regulamentação das caçadas e proteção da fauna silvestre, concedeu entrevista à imprensa. Além de Mello Leitão, compunham a referida comissão Edgar Roquette-Pinto, antropólogo do Museu Nacional desde 1906, e Alberto Sampaio, botânico da mesma instituição desde 1905. Os três tinham uma longa história em comum, pois frequentaram a Faculdade de Medicina do Rio de Janeiro no alvorecer do século XX, influenciados pela mesma formação de história natural de cunho fortemente teórico. ${ }^{16}$ Mello Leitão trabalhava no Museu desde 1931, como 
professor de zoologia, acumulando ainda cargos na Escola Superior de Agricultura e Veterinária, na cátedra de zoologia agrícola, e no Instituto de Educação, como chefe da cadeira de Biologia Geral.

$\mathrm{Na}$ entrevista, o zoólogo argumentava como a defesa da fauna, assim como das riquezas naturais, era uma preocupação essencial dos países civilizados. Várias nações possuíam leis de controle da caça, paralelamente à criação de parques naturais. Citando o exemplo das leis uruguaias e argentinas, destacava a importância de o Brasil sintonizar-se com o urgente estabelecimento de práticas de defesa do seu patrimônio natural. ${ }^{17} \mathrm{~A}$ atuação do zoólogo foi destacada e estreitamente ligada às instâncias do poder instituído, assim como ocorreu com vários de seus colegas do Museu Nacional. Vivia-se uma época marcada por grandes agitações políticas e por verdadeira reviravolta nos rumos da sociedade brasileira.

A aproximação de uma parcela da elite intelectual com o Estado pós-1930 pode ser bem exemplificada pelas práticas dos cientistas do Museu Nacional. A comissão aqui mencionada não deixou de render frutos: em janeiro de 1934 surgiu o primeiro Código de Caça e Pesca brasileiro (Decreto 23.672). Em julho do mesmo ano, o Decreto-lei 24.645 regulamentou o tratamento dedicado aos animais, prevendo atitudes inadequadas, assim como multas e penalidades para os infratores, colocando todos os animais do país sob tutela do Estado.

Mello Leitão atuava em várias instituições simultaneamente, mas o Museu Nacional assumiu um papel primordial na sua projeção nacional e internacional. Essa instituição foi amplamente privilegiada pelo governo de Vargas, na medida em que se sintonizou com o apelo da necessidade de uma redescoberta do Brasil, da conquista e do conhecimento do seu território, da valorização de seu solo, seu povo, sua hidrografia, sua fauna e flora.

O diretor do Museu Nacional, Edgar Roquette-Pinto, nomeado para presidir a Comissão de Censura Cinematográfica instituída pelo governo em 1931, passou a receber a verba gerada pelo pagamento de taxas sobre os filmes exibidos para financiar a Revista Nacional de Educação, publicada entre 1932 e 1934, sob os auspícios do Ministério da Educação e Saúde Pública, em expressiva tiragem. Seu objetivo principal era a veiculação de conteúdos de ciência, história e arte para um público mais amplo das várias regiões do Brasil. Os artigos eram assinados por intelectuais, muitos deles atuantes cientistas do Museu Nacional. Apresentando-se como iniciativa de uma República renovada, parte de estratégia mais ampla de inaugurar novas relações entre o governo e uma população a ser educada, a Revista se autodefiniu como "um marco es- 
piritual da nacionalidade", sintonizada ao ideal de um Estado cuja ação pedagógica constituísse um povo e uma nação. Entre os mais assíduos autores encontravam-se Mello Leitão e Alberto Sampaio, membro fundador da Sociedade dos Amigos das Árvores, relator-geral e principal organizador da I Conferência Brasileira de Proteção à Natureza, realizada em abril de 1934 e também financiada pelo governo Vargas. ${ }^{18}$

Naqueles anos, o Museu Nacional afinou-se às ideias, então muito em voga, de renovação da sociedade por meio da educação. Após décadas de debates dos eugenistas sobre as heranças genéticas das raças no Brasil, nos quais muitas vezes predominou a visão pessimista de que o povo brasileiro estava fatalmente destinado ao fracasso, prevaleceu a postura de que não se estava diante de um problema de falta da qualidade racial, mas sim da ausência de uma boa educação e de condições higiênicas. Superadas tais condições, o Brasil, erigido sobre um território deslumbrantemente rico, poderia contar com um povo e caminhar ao destino de uma grande Nação.

Como evidência da aproximação entre o Museu e o movimento da Escola Nova, podemos citar a inauguração, por Roquette-Pinto e Anísio Teixeira (primeiro tradutor de John Dewey no Brasil), de uma rádio educativa, nas dependências da escola Instituto de Educação. A emissora veiculava programas diários de divulgação do conhecimento produzido no Museu, com ampla participação de cientistas como Mello Leitão e Alberto Sampaio, além do próprio Roquette-Pinto. Outro dos maiores idealizadores do movimento educacional, Fernando Azevedo, lançou-se a um dos primeiros e mais importantes empreendimentos editoriais realizados no Brasil, organizando a Biblioteca Pedagógica, com cinco coleções: Iniciação científica, Livros infantis, Livros didáticos, Atualidades pedagógicas e Brasiliana. Esta última tinha como objetivo principal traduzir e disponibilizar obras de viajantes europeus sobre o Brasil, além de publicar as obras de autores brasileiros, possibilitando "redescobrir o Brasil aos Brasileiros". Entre seus autores, muitos eram do Museu Nacional, como Sampaio, Roquette-Pinto e Mello Leitão - que publicou cerca de dez obras na Biblioteca Pedagógica, além de ter traduzido e organizado mais três livros. ${ }^{19}$

Provavelmente o contato mais íntimo com tais práticas e discussões no ambiente do Museu, assim como no Instituto de Educação (instituição diretamente envolvida na renovação educacional), levou Mello Leitão a rever suas posições fortemente deterministas acerca do papel da herança genética, tal como exposto nos artigos de 1922, já comentados. Sua participação na organização de exposições, palestras na rádio educativa e artigos de divulgação na Revista Nacional de Educação evidenciam seu envolvimento num amplo mo- 
vimento intelectual de mobilização em prol da educação do povo brasileiro como caminho de construção nacional.

Em torno desse ideal pedagógico, certamente se reuniram propostas políticas de matizes realmente diversos, enunciadas por personagens de posturas variadas. A mobilização em torno dos apelos da Escola Nova foi comum não só a um homem como Anísio Teixeira, de franca posição liberal - muitas vezes discriminado como comunista -, mas também a Mello Leitão, conservador, religioso e anticomunista.

As posturas políticas de Mello Leitão mais uma vez se evidenciam nos artigos de divulgação científica então publicados na Revista Nacional de Educação, vários deles originados de palestras veiculadas através da rádio educativa. Neles, predominava a mesma concepção de uma natureza orgânica e harmoniosa, sem conflitos, numa teia de interdependências e colaborações, em clara sintonia com as perspectivas corporativistas em ascensão nos projetos políticos brasileiros, e que ganhariam destaque a partir de 1937. Na era Vargas, várias leis trabalhistas e uma estrutura sindical organizada pelo Estado pressupunham a solidariedade dos interesses concretos da qual derivariam fórmulas de colaboração, com a remoção ou neutralização dos conflitos, fossem eles lutas de classes ou diferenças ideológicas. Esta era exatamente a perspectiva de Mello Leitão sobre a natureza, veiculada através de seus artigos, livros, aulas e palestras.

Na construção de textos destinados ao grande público, uma das suas maiores inspirações vinha de Jean-Henri Fabre (1823-1915), entomólogo francês famoso por sua oposição à teoria da seleção natural de Darwin. Fabre abusou da escrita poética, chave da imensa popularidade de seus livros. Alcançou grande aceitação entre grupos conservadores e católicos europeus, graças à sua apologia dogmática da humildade da inteligência frente ao incognoscível e à sua perspectiva da biologia como um verdadeiro catecismo natural da teologia. ${ }^{20}$ Evocando repetidas vezes o escritor francês, Mello Leitão se esmerou na construção de textos literários, repletos de imagens poéticas e referências culturais na veiculação de suas concepções sobre a natureza.

Sob esse aspecto, seus artigos são verdadeiros exercícios de erudição, afastados da taxonomia classificatória cansativa e insossa para o leitor comum, e constroem um texto saboroso, temperado com imagens poéticas e sedutoras de um mundo de maravilha, mistério e perfeição, repleto de lendas, fábulas e referências culturais diversas.

Para discorrer sobre as teias de aranhas, Mello Leitão recorre à narrativa helênica de Aracne, às lendas astecas, às referências encontradas em Dante, às 
lendas indígenas do Brasil. Na floresta, na campina, no descampado, milhares de aranhas viviam como numa Liliput admirável, algumas de roupagem modesta, outras tecendo fios elegantes. Em texto sobre as cigarras, o autor relembra a fábula de La Fontaine, reproduz a ilustração realizada por Gustave Doré, refere-se aos costumes dos chineses antigos, que aprisionavam as cigarras em pequenas gaiolas, lista citações de Anacreonte, Homero, Esopo, Platão e Aristóteles, este último um grande apreciador das fêmeas cheias de ovos como petisco. Em artigo sobre rãs, Mello Leitão refere-se à sua presença constante nas práticas de bruxaria medievais; à descrição por Shakespeare, em Macbeth, ao uso do seu veneno em feitiços; às narrativas da Batracomiomaquia, atribuída a Homero; ou ainda às alusões de Edmond Rostand ao sapo como símbolo da inveja e da adulação. Acerca dos celentéreos (ou celenterados), destacava casos célebres de envenenamento no século XVIII pelo uso de suas substâncias tóxicas. ${ }^{21}$

Os textos de Mello Leitão podem ser comparados, nesse aspecto, aos autores de história natural dos séculos XVI e XVII, que, antes de a taxonomia de Lineu reduzir a descrição aos aspectos visíveis e observáveis dos seres vivos, criavam narrativas repletas de referências lendárias e recolhiam heranças da Antiguidade, na tentativa de reunir todas as informações possíveis, já que qualquer uma delas poderia ser importante na decifração dos mistérios da natureza. Descrever um inseto ou qualquer outro ser vivo era narrar tudo o que se poderia dizer sobre ele (Foucault, 2000, p.176). Entretanto, o zoólogo definitivamente se afastava das formas de pensamento renascentista. Dentro da sua perspectiva biológica, tais narrativas assumiram um sentido historicamente inédito: tratava-se de constituir uma espécie de lastro cultural para seus leitores, ligá-los a uma tradição cultural ocidental, na qual sorvessem grandes referências literárias do mundo clássico. Fazia-se necessário também o estabelecimento de alguns relatos originários das populações indígenas do Brasil. Tal erudição tinha, portanto, o propósito pedagógico de elevar o nível cultural dos leitores aos quais Mello Leitão se dirigia e, simultaneamente, valorizar uma cultura apresentada como autenticamente nativa, genuinamente brasileira, que estivesse à altura de um território enaltecido por suas riquezas naturais (Duarte, 2004, p.38).

O desdobramento do biólogo em fabulista evidenciava, ainda, outro aspecto essencial, a saber, a clara defesa do estudo da natureza e da vida animal - hábitos, costumes, formas de organização - como um meio de extrair verdades inquestionáveis e passíveis de serem estendidas para se pensar a sociedade humana. Tal perspectiva foi comum entre vários cientistas contemporâ- 
neos a Mello Leitão (Mitman, 1992, p.7, 48-71). Se as fábulas são, em grande parte, protagonizadas por animais e sempre direcionadas à enunciação de preceitos e lições morais, o biólogo-fabulista exercia uma prática discursiva de transferência direta das conclusões acerca dos animais para as sociedades humanas, explicitando a premissa de que o estudo da natureza poderia servir como guia de preceitos seguros a serem seguidos pelos homens.

A constituição dos saberes biológicos ocorria numa arena política, em que a enunciação de concepções sobre a organização social se revestia da autoridade científica para se apresentar como racional e, sobretudo, inquestionável. Assim, mediante a descrição das cigarras, Mello Leitão louvava a importância dos sábios e professores para a sociedade, e seu texto sobre as aranhas elogiavaas como exemplo de labor, operosidade, paciência e engenho, assim como mostrava uma sociedade de desigualdades, mas nem por isso menos harmoniosa; e assim por diante.

A perspectiva pragmática de que o conhecimento deveria ser ministrado com base em experiências próximas e no estímulo à observação levou nosso autor a adotar ainda outro tipo de estratégia narrativa para atrair seus leitores e afirmar determinada visão da natureza. Uma das formas retóricas mais comuns nos textos de divulgação era partir de eventos bem conhecidos dos leitores e ouvintes (no caso das palestras veiculadas na rádio). Sobre os celentéreos, Mello Leitão lembra-se de um caso então noticiado pelos jornais, de uma senhora que, banhando-se na praia de Copacabana, tocou numa água-viva e sofreu graves queimaduras. Com base nesse relato, passa a descrever tais seres, detalhando as várias espécies, descrevendo sua morfologia e/ou veiculando desenhos científicos. Sobre as cigarras, nota que não passariam despercebidas de nenhum morador do Rio de Janeiro, pois cantavam durante os dias de verão ardentes, "agarradas aos ramos das árvores dos parques e jardins".

Mas uma vez citando um fato cotidiano, apressava-se em apontar as incorreções dos conhecimentos do vulgo. Notava que eram, por vezes, confundidas com grilos, e por isso se lhes atribuíam hábitos carnívoros. Explicava também que a cigarra produz um líquido adocicado, do qual a própria formiga por vezes se alimenta, o que evidentemente contrariava a fábula. Também a troca do revestimento externo muitas vezes era apontada como resultado de um estouro por cantar muito alto, mas o entomólogo explicava que tal ruptura era a simples passagem à forma alada e ao início da vida sonora ao ar livre, após anos de vida subterrânea.

Sobre os sapos, instigava: "quem ainda não ouviu, quebrando triste e monótono o silêncio da noite, o canto triste dos sapos?”. Mas após breve introdu- 
ção poética, apressava-se a explicitar que as ideias populares eram absolutamente erradas. Assim, se as glândulas dos sapos produziam um líquido tóxico e irritante para a córnea, logo se firmava a crença popular de que a urina do sapo causava cegueira.

Os artigos apresentavam um ponto de observação comum entre o leigo e o cientista para logo desprezarem as concepções populares e correntes, acrescentando, na sequência do texto, uma série de "informações confiáveis". A experiência do leitor, assim, era evocada tão-somente para ser desvalorizada, predominando a ideia de que o biólogo era um intermediário indispensável entre o homem comum e a natureza ao seu redor, numa perspectiva pedagógica certamente coerente com o autoritarismo de Mello Leitão. Evidenciava-se a ambiguidade entre a ideia geral de que a "cultura nativa" deveria ser valorizada e a concepção de que a população ignorante e supersticiosa deveria ser educada pelas elites intelectuais, combatendo seus "erros vulgares". ${ }^{22}$

Naqueles anos de grandes expectativas para os rumos da sociedade brasileira, quando o governo provisório de Vargas ainda se oferecia como um campo de possibilidades no qual se abrigavam projetos políticos de diversos matizes, Mello Leitão tornou-se cientista de crescente destaque, trabalhando num meio intelectual bastante rico. Mas ele certamente exemplifica o tipo de intelectual cujo viés autoritário possibilitaria a permanência de seu prestígio e a manutenção do apoio governamental após a instalação da ditadura de Vargas, em 1937.

\section{O "FABRE BRASILEIRO”: BIOLOGIA E POESIA EM TEMPOS DIFÍCEIS}

Mello Leitão foi um dos autores que mais escreveu na Biblioteca Pedagógica. Todos os seus livros privilegiam uma escrita de elegância e erudição, aliada a marcante intenção literária. Publicou obras enfocando a visão dos viajantes sobre o Brasil e a biologia como campo de conhecimento através da história deste país, além de um livro pioneiro sobre a zoogeografia brasileira. Organizou e realizou traduções comentadas de obras de viajantes. Publicou dois compêndios didáticos de biologia. Dedicou especialmente dois livros ao grande público, na série Iniciação Científica: A vida maravilhosa dos animais e $A$ vida na selva. ${ }^{23}$

Em 1935, A vida maravilhosa dos animais alcançou grande sucesso de crítica e mereceu a atenção das colunas literárias de vários jornais. Múcio Leão, da Academia Brasileira de Letras, dedicou-lhe elogiosa resenha, atribuindo a Mello Leitão a conciliação entre o rigor da ciência e o conhecimento prazero- 
so dos aspectos pitorescos do mundo animal. Lúcia Miguel Pereira, cronista destacada, sublinhou o interesse pela obra, que a levara a refletir sobre como o estudo dos animais poderia trazer lições sobre a vida humana e a sociedade. Outra resenha, anônima, comentava como a obra conduzia "pelo reino encantado da zoologia”, ensinando muito e divertindo à proporção do ensino. No "livro do mestre", muito havia o que louvar e aproveitar, pois a exposição da máquina da vida "complexa e harmoniosa" revelava a causa primeira inteligente, que tudo ordena, prevê e provê. Curiosamente, também Maurício de Lacerda, membro da Aliança Nacional Libertadora, fundada em março de 1935 com o objetivo de combater a expansão do fascismo e o imperialismo, notava como o livro de Mello Leitão, o "Fabre Brasileiro", ao descrever o parasitismo e o comensalismo, ajudava na compreensão de várias práticas das elites brasileiras, numa interpretação certamente não autorizada pelo autor (Leão, 1935; Pereira, 1935; Lacerda, 1935). ${ }^{24}$

O ano de publicação da obra foi também um ano de grandes turbulências políticas. Após a promulgação da Constituição de 1934, Getúlio Vargas foi eleito presidente da República por votação indireta e incrementou a criação de leis sindicais corporativistas. Em março de 1935 surgiu a Aliança Nacional Libertadora, levantando as bandeiras da suspensão do pagamento da dívida externa do país, da nacionalização das empresas estrangeiras, da reforma agrária e da proteção aos pequenos e médios proprietários, e exigindo a garantia de amplas liberdades democráticas. Em abril, sob o impacto de uma onda de greves, o governo promulgou a Lei de Segurança Nacional, definindo crimes contra a ordem política e social e contra a segurança do Estado, transferindo-os para uma legislação especial e submetendo-os a um regime mais rigoroso, com o abandono das garantias processuais. Em julho, a Aliança foi decretada ilegal. A partir de então, ocorreram várias manifestações e levantes comunistas. Em novembro, Vargas decretou o estado de sítio, estendido até os primeiros meses de 1936. O acirramento desses conflitos levaria ao golpe de Estado de 1937, com o fechamento do Congresso Nacional e a outorga de uma Constituição autoritária. Iniciou-se um regime centralizador, autoritário, de forte apelo anticomunista, mesclando paternalismo a uma postura nacionalista e industrializante, o que acabou por garantir a adesão de grande parcela da população, apreensiva diante dos indícios de nova guerra mundial.

Em tempos tão duros, a leveza e o tom poético de $A$ vida maravilhosa dos animais provavelmente constituíram-se em fatores de apaziguamento da angústia de muitos dos seus leitores. A comparação com Fabre não era espontâ- 
nea: na realidade, ela foi induzida pela própria edição da obra de Mello Leitão, que trazia na capa uma imensa foto do francês. Ali se reuniu uma série de conferências realizadas pouco antes. Os textos reforçam as interpretações já discutidas aqui, entre as quais a valorização do mistério, a interpretação da natureza a partir de pressupostos eminentemente políticos, o uso de argumentos científicos para justificar certas concepções sobre a sociedade, o combate ao darwinismo e a defesa da noção de harmonia e organicidade, a erudição, o combate aos erros vulgares, o recurso às fábulas como meio de agregar valores morais e, também, a escrita literária.

Focalizando a vida social dos animais, Mello Leitão os hierarquizava, relacionando o seu índice de superioridade à capacidade de vida social. Em sua concepção, as formigas alcançavam alto nível, pois desenvolviam amizade, linguagem, asseio, solidariedade, bondade, e, sobretudo, obediência às regras coletivas. "Na mais estreita disciplina e na ordem mais perfeita" submetiam-se a um regime severo, sacrificando-se. Que os homens aprendessem: sendo o homem superior, seu destino inexorável era fazer do trabalho um prazer. Cada um era "uma formiga anônima e diligente", e deveria dar o melhor de si ao seu lar, à sua cidade, à sua pátria e à humanidade, até que a morte trouxesse a hora do descanso. Contrariando a ideia de conflito, o autor destacava a solidariedade entre as aves, entre os elefantes, entre as marmotas e entre os insetos, observando "que a natureza é sempre uma grande harmonia, onde a mútua dependência, o auxílio, diríamos mesmo a amizade, é a regra geral". ${ }^{25}$ Havia uma clara apropriação da teoria do apoio mútuo, de Piotr Kropotkin, cuja obra foi bastante valorizada entre inúmeros biólogos nas primeiras décadas do século XX (Mitman, 1992, p.67). É claro que Mello Leitão reinterpretou a seu modo os escritos do príncipe anarquista russo, ignorando seu conteúdo libertário e laico, acomodando-os à sua visão religiosa e transcendental da natureza, utilizando-os para reforçar seus argumentos antidarwinistas.

Enquanto o governo Vargas estimulava um sindicalismo subserviente e o corporativismo social, Mello Leitão elogiava as aranhas, "obreiras imperturbáveis, em seu manejo paciente", "modestas e silenciosas". Apontava a sofisticação dos macacos e suas sociedades baseadas na divisão do trabalho, na solidariedade e no sentimento de compaixão entre os indivíduos e, sobretudo, na "mais cega obediência aos chefes". Argumentos semelhantes foram utilizados para que o autor discorresse sobre pelicanos, cegonhas, marmotas, cupins, pinguins, pardais e tantos outros animais. ${ }^{26}$ 


\section{Conclusẽo}

Nos anos que se seguiriam, Mello Leitão continuaria acumulando louros profissionais, com a publicação de inúmeros outros livros e a continuidade do apoio governamental. Em abril de 1937, poucos meses antes do golpe de Estado, o autor foi indicado para representar o Brasil em congresso na Argentina e viajou com patrocínio federal. Em entrevista ao periódico La Libertad foi identificado como la más alta autoridad em arañas. Defendia a concepção de uma natureza divina, transcendente, fonte de verdade, reveladora de essências. Diante do mistério e milagre da vida, declarava-se criacionista. ${ }^{27}$

A análise da obra de Mello Leitão exemplifica como, sob a pretensa neutralidade da ciência, as concepções sobre o mundo natural são sempre construídas historicamente, no âmbito das lutas sociais e do enfrentamento dos diferentes projetos dos atores sociais. A biologia desse autor expressa claramente uma concepção de natureza sob viés eminentemente autoritário, predominante nos rumos políticos da nação brasileira daquelas décadas. Sua ascensão profissional não deixa de ser simbólica em relação ao fortalecimento de um projeto conservador no qual houve destaque imenso para a natureza, com a valorização do seu estudo e de sua proteção.

Durante a ditadura Vargas, outros decretos de proteção à natureza seriam aprovados, como no caso da criação dos primeiros parques nacionais, em 1937 e 1939. Entretanto, esses projetos se organizavam de cima para baixo, atingindo uma sociedade civil crescentemente silenciada e oprimida, conclamada à obediência, à concordância, à aceitação de relações paternalistas da proteção trabalhista de um Estado autoritário, muito bem resumida na imagem de Getúlio Vargas como "pai dos pobres".

A partir de meados da década de 1940, e especialmente no pós-guerra, tendo em vista a nova configuração mundial e os interesses industrializantes das elites internas, as concepções conservacionistas da natureza perderam espaço. Frente a uma verdadeira febre desenvolvimentista, afirmada decisivamente na década de 1950 por setores de matizes políticos os mais variados, o discurso de proteção da natureza aparecia, antes, como um obstáculo ao progresso da nação.

Uma vez finda a ditadura, em 1945, a rejeição a tudo que lembrasse a "Era Vargas" pode ter reforçado o desprezo pelas questões ambientais, identificadas com o nacionalismo ufanista até então predominante. No seio daquele projeto político autoritário, a busca da valorização da natureza como fonte inquestionável de verdade acabou por colocá-la acima dos homens, transcendente à 
sociedade. Foi idealizada nos versos de sambas, como Aquarela do Brasil. Apresentou-se estereotipada nos adornos tropicais de uma Carmen Miranda hollywoodiana. Surgiu misteriosa e pródiga em lições morais de obediência, trabalho abnegado e conformismo, nas páginas literariamente sedutoras do professor Mello Leitão.

\section{Agradecimentos}

A autora agradece ao $\mathrm{CNPq}$, à Fapemig, aos pesquisadores do projeto Coleção Brasiliana: leituras e escritos da Nação (1931-1941) e aos funcionários do Arquivo do Museu Nacional da UFRJ.

\section{NOTAS}

${ }^{1}$ El Imparcial, El Diário, El Debate e La Mañana (Montevideo, 23 out. 1931, 24 out. 1931); La Nación (Buenos Aires, 30 mar. 1937); La Libertad (Buenos Aires, 11 abr. 1937); La Razon, El Mundo Uruguaio e La Mañana (Montevideo, 2 set. 1945, 4 set. 1945, 5 set. 1945; 12 set. 1945); A Noite (Rio de Janeiro, 1 out. 1945). In: MELLO LEITÃO, C. Coletânea de notícias referentes a atividades de maior projeção, obras e conferências . Arquivo do Museu Nacional, Rio de Janeiro, BR MN JF O MN DR 3 1925-1948. Ao longo da década de 1930, delinear-se-ia uma política externa brasileira voltada para a América Latina, como exposto por BERABA, Ana Luiza. América aracnídea: teias culturais interamericanas. São Paulo: Civilização Brasileira, 2008, p.37.

${ }^{2}$ ESTABLE, Clemente. Presentación del Profesor Mello Leitão. Anales de la Facultad de Medicina de Montevideo, v.XXX, n.12, p.947-949, 1945; KURY, Adriano B.; BAPTISTA, Renner L. C. "Arachnological papers published by Cândido Firmino de Mello-Leitão (Arachnida)". Publicações avulsas do Museu Nacional, v.105, p.1-17, 2004; DUARTE, Regina Horta. "Nação, natureza e território: Candido de Mello Leitão e a biologia no Brasil". Territórios e fronteiras, v.1, n.1, p.141-155, 2000; FRANCO, José Luiz de Andrade; DRUMMOND, José Augusto. "Cândido de Mello Leitão: as ciências biológicas e a valorização da natureza e da diversidade da vida”. História, Ciências, Saúde - Manguinhos, v.14, n.4, p.1265-1290, 2006.

${ }^{3}$ BENCHIMOL, Jaime Larry. “Origens e evolução do Instituto Oswaldo Cruz no período 1899-1937”. In: BENCHIMOL, Jaime Larry (Org.). Manguinhos do sonho à vida: a ciência na Belle Époque. Rio de Janeiro: Fiocruz/Casa de Oswaldo Cruz, 1990, p.7; BENCHIMOL, Jaime Larry; TEIXEIRA, Luiz Antonio. Cobras, lagartos e outros bichos: uma história comparada dos institutos Oswaldo Cruz e Butantan. Rio de Janeiro: UFRJ/Fiocruz, 1993, p.13109; SILVA, André Felipe Cândido da. "A campanha contra a broca-do-café em São Paulo (1924-1927)”. História, Ciências, Saúde - Manguinhos, v.13, n.4, p.957-993, 2006; 
FONSECA, Maria Rachel Froes da. "Escola Superior de Agricultura e Medicina Veterinária”. In: Dicionário Histórico-biográfico das Ciências da Saúde no Brasil (1823-1930). Casa de Oswaldo Cruz/Fiocruz. Disponível em: www.dichistoriasaude.coc.fiocruz.br; acesso em: 23 jun. 2009.

${ }^{4}$ Sobre eugenia nos meios intelectuais no Brasil da Primeira República: LUCA, Tania de. A Revista do Brasil: um diagnóstico para a (N)ação. São Paulo: Ed. Unesp, 1999, p.131-201 e 223-230; LIMA, Nisia Trindade. Um sertão chamado Brasil. Rio de Janeiro: Revan, 1999, p.115-117; SCHWARCZ, Lilia Moritz. O espetáculo das raças: cientistas, instituições e questão racial no Brasil, 1870-1930. p.215-217, 235-238; SILVA, João Italo de Oliveira e. Por uma eugenia latino-americana: Victor Delfino e Renato Kehl. Dissertação (Mestrado em História) - UFMG. Belo Horizonte, 2008.

${ }^{5}$ Sobre a especialização dos saberes em curso nesse período, com destaque para a fundação da Academia Brasileira de Ciências em 1916 (da qual eram membros vários pesquisadores do Museu Nacional), ver: MOREIRA, Ildeu de C.; MASSARANI, Luisa. "A divulgação científica no Rio de Janeiro: algumas reflexões sobre a década de 1920". História, Ciências, Saúde - Manguinhos, v.7, n.3, p.627-651, 2001; SÁ, Dominichi Miranda de. A ciência como profissão: médicos, bacharéis e cientistas no Brasil (1895-1935). Rio de Janeiro: Fiocruz, 2006, p.73-88. Sobre o surgimento da biologia como ciência da vida, diversa da história natural, ver: FOUCAULT, Michel. As palavras e as coisas. São Paulo: Martins Fontes, 2000, p.175-180, 310-318, 362-385.

${ }^{6}$ LIMA, Nísia Trindade; SÁ, Dominichi Miranda de. "Roquette-Pinto e sua geração na república das letras e da ciência”. In: LIMA; SÁ (Org.). Antropologia brasiliana: ciência e educação na obra de Edgard Roquette-Pinto. Rio de Janeiro: Ed. Fiocruz; Belo Horizonte: Ed. UFMG, 2008, p.57-63; CAPANEMA, Carolina. A natureza no projeto de construção de um Brasil moderno e a obra de Alberto José de Sampaio. Dissertação (Mestrado em História) - UFMG. Belo Horizonte, 2006; DUARTE, Regina Horta. "Em todos os lares, o conforto moral da ciência e da arte: a Revista Nacional de Educação e a divulgação científica no Brasil (1932-1934)". História, Ciências, Saúde - Manguinhos, v.11, n.1, p.33-56, 2004; FRANCO, José Luiz de A.; DRUMMOND, José A. Proteção à natureza e identidade nacional no Brasil, anos 1920-1940. Rio de Janeiro: Ed. Fiocruz, 2009.

${ }^{7}$ PAULY, Philip. Biologists and the promise of American life. Princeton: Princeton University Press, 2000, p.3-7, 10, 166-169; MITMAN, Gregg. The state of nature: ecology, community and American social thought, 1900-1950. Chicago: University of Chicago Press, 1992, p.7, 45-71. Ver ainda McCOOK, Stuart. States of nature: science, agriculture and environment in the Spanish Caribbean 1760-1940. Austin: University of Texas Press, 2002, p.5, 20-28, 128-129.

${ }^{8}$ MELLO LEITÃO. "O estudo da História Natural”. Recorte de jornal, 11 e 13 abr. 1923, Arquivo do Museu Nacional, Rio de Janeiro, BR MN JF O MN, DR.2, 1921-1923.

${ }^{9}$ MELLO LEITÃO. "Hereditariedade dos caracteres adquiridos". Recorte de jornal, 7 e 14 jul. 1922, Arquivo do Museu Nacional, Rio de Janeiro, BR MN JF O MN, DR.2, 19211923. 
10 "Mendelismo e eugenia", Recorte de jornal, 16 e 23 mar. 1923, 1 abr. 1923, Arquivo do Museu Nacional, Rio de Janeiro, BR MN JF O MN, DR.2, 1921-1923.

${ }^{11}$ Respectivamente: MELLO LEITÃO. “Sem título”. 17 fev. 1922; “O mais velho dos poetas..." (s.d.), "Mendelismo e eugenia”. 1 abr. 1923. Recortes de jornal, Arquivo do Museu Nacional, Rio de Janeiro, BR MN JF O MN, DR.2, 1921-1923.

${ }^{12}$ BARBOUR, Michael. "Ecological fragmentation in the Fifties". In: CRONON, W. (Ed.). Uncommon Ground. New York/London: W. W. Norton \& Company, 1996, p.238.

${ }^{13}$ GUALTIERI, Regina C. E. "O evolucionismo na produção científica do Museu Nacional”. In: DOMINGUES, Heloisa M. Bertol; SÁ, Magali R.; GLICK, Thomas (Org.). A recepção do darwinismo no Brasil. Rio de Janeiro: Ed. Fiocruz, 2003, p.80; DUARTE, Regina H. "Evolutionism, anti-Darwinism and society in Brazil". Jarbuch für Europäische Wissenschaftskultur, v.2, n.1, 2006, p.147-158.

${ }^{14}$ MELLO LEITÃO. "Fé evolucionista e dúvidas modernas". Recorte de jornal, 28 abr. 1922, Arquivo do Museu Nacional, Rio de Janeiro, BR MN JF O MN, DR.2, 1921-1923.

${ }^{15}$ MELLO LEITÃO. “Teia da vida”. Recorte de jornal, 27 out. 1922, Arquivo do Museu Nacional, Rio de Janeiro, BR MN JF O MN, DR.2, 1921-1923.

${ }^{16}$ MELLO LEITÃO. "O estudo da História Natural”. Recorte de jornal, 11 e 13 abr. 1923, Arquivo do Museu Nacional, Rio de Janeiro, BR MN JF O MN, DR.2, 1921-1923.

${ }^{17}$ MELLO LEITÃO, C. de. "Protegendo a nossa fauna silvestre" (entrevista) A noite, Rio de Janeiro, 13 fev. 1933. Recorte, Coletânea de notícias referentes a atividades de maior projeção, obras e conferências, Arquivo do Museu Nacional, Rio de Janeiro, BR MN JF O MN DR 3 1925-1948.

${ }^{18}$ DUARTE, Regina H. “Em todos os lares...”, cit., 2004; CAPANEMA, Carolina. A natureza no projeto de construção..., cit., 2006, p.20-43; DRUMMOND; FRANCO. Proteção à natureza e identidade nacional..., cit., 2009, p.43-64.

${ }^{19}$ VIDAL, Diana. O exercício disciplinado do olhar: livros, leituras e práticas de formação docente no Instituto de Educação do Distrito Federal (1932-1937). Bragança Paulista (SP): Ed. Universidade São Francisco, 2001, p.101-127; DUTRA, Eliana. “A nação nos livros: a biblioteca ideal na coleção brasiliana”. In: DUTRA; MOLLIER (Org.). Política, nação e edição. São Paulo: Annablume, 2006, p.299; DUARTE, Regina Horta. "Biologia e sociedade no Brasil dos anos 1930: práticas de escrita e divulgação científica em Cândido de Mello Leitão”. In: CONDE; FIGUEIREDO (Org.). Ciência, história e teoria. Belo Horizonte: Argumentum, 2005, p.13-40; LIMA, Nísia Trindade. “A raça brasileira”. In: LESSA, Carlos (Org.). Enciclopédia da Brasilidade: autoestima em verde e amarelo. Rio de Janeiro: Casa da Palavra, 2005, p.102-115.

${ }^{20}$ FAVRET, Colin. "Jean-Henri Fabre: his life experiences and predisposition against Darwinism”. American Entomologist, v.45, n.1, p.38-48, 1999; TORT, Patrick. Fabre, le miroir aux insectes. Paris: Éd. Vuibert, 2002.

${ }^{21}$ Respectivamente publicados na Revista Nacional de Educação: MELLO LEITÃO, “Ce- 
lentérios”, v.I, n.5, p.17-23, 1933; “As cigarras”, v.I, n.6, p.3-8, 1933; "Vida das aranhas: o lar”, v.I, n.7, p.9-44, 1933; “As aranhas: sua posição sistemática, seus afins”, v.I, n.8, p.5-9, 1933; “Teias de aranha”, v.II, n.9, p.5-10, 1933; “A vida das rãs”, v.II, n.13/14, p.1-6, 1933.

${ }^{22}$ THOMAS, Keith. O homem e o mundo natural. São Paulo: Companhia das Letras, 1998, p.84-96.

${ }^{23}$ São obras de MELLO LEITÃO na Biblioteca Pedagógica: Visitantes do Primeiro Império. (Coleção Brasiliana, 32). São Paulo: Cia. Ed. Nacional, 1934; A vida maravilhosa dos animais. (Série Iniciação Científica, 7). São Paulo: Cia. Ed. Nacional, 1935; Zoogeografia do Brasil. (Coleção Brasiliana, 77). São Paulo: Cia. Ed. Nacional, 1937; O Brasil visto pelos ingleses. (Coleção Brasiliana, 82). São Paulo: Cia. Ed. Nacional, 1937; A Biologia no Brasil. (Coleção Brasiliana, 99). São Paulo: Cia. Ed. Nacional, 1937; Biologia geral - de acordo com os programas dos cursos pré-universitários. 2.ed., refundida e atualizada. (Série Livros Didáticos, 42). São Paulo: Cia. Ed. Nacional, 1940; História das expedições científicas ao Brasil. (Coleção Brasiliana, 209). São Paulo: Cia. Ed. Nacional, 1941; A vida na selva. (Série Iniciação Científica, 20). São Paulo: Cia. Ed. Nacional, 1940; Compêndio Brasileiro de Biologia. 2v. (Série Livros Didáticos). São Paulo: Cia. Ed. Nacional, 1943. Traduções: BATES, Henry W. O naturalista no rio Amazonas. (Coleção Brasiliana, 237/237a). Tradução e notas de Cândido de Mello Leitão. São Paulo: Cia. Ed. Nacional, 1944; CARVAJAL, Gaspar de; ROJAS, Alonso; ACUÑA, Cristobal. Descobrimentos do Rio das Amazonas. (Coleção Brasiliana, 203). Tradução, reunião e notas de Cândido de Mello Leitão. São Paulo: Cia. Ed. Nacional, 1941.

${ }^{24}$ LEÃO, Mucio. "Registro literário: a vida maravilhosa dos animais”. Jornal do Brasil, s.d. (recorte); PEREIRA, Lucia Miguel. "Livros: A vida maravilhosa dos animais". Gazeta de Notícias, 25 ago. 1945 (recorte); LACERDA, Maurício de. "O comedor de escorpiões, comensalismo, parasitismo, imperialismo...”. O Imparcial, 9 ago. 1935 (recorte). Coletânea de notícias referentes a atividades de maior projeção, obras e conferências. Arquivo do Museu Nacional, Rio de Janeiro, BR MN JF O MN DR 3 1925-1948.

${ }^{25}$ MELLO LEITÃO, A vida maravilhosa dos animais..., cit., 1935, p.37, 63.

${ }^{26}$ Ibidem, 1935, p.27, 155.

${ }^{27}$ MELLO LEITÃO. “Entrevista”. La Libertad, 11 abr. 1937 (recorte). Coletânea de notícias referentes a atividades de maior projeção, obras e conferências. Arquivo do Museu Nacional, Rio de Janeiro, BR MN JF O MN DR 3 1925-1948.

Artigo recebido em agosto de 2009. Aprovado em outubro de 2009. 